\title{
Director Jeffery Jeturian
}

\author{
By Yvonne Ng
}

Spring 2002 Issue of KINEMA

\section{DIRECTOR JEFFERY JETURIAN IN CONVERSATION WITH YVONNE NG}

Born in 1959, Filipino director Jeffrey Jeturian won critical acclaim with his first feature drama, I Wish It Were Love (Sana pag-ibig na) in 1998. His second film Fetch a Pail of Water (Pila-balde, 2000), about life in the slums, received the Gold Award at the 2000 Worldfest International Film Festival in Houston, Texas and enjoyed commercial and critical success at home. It has played at numerous festivals, among them the Far East Film festival in Udine, Italy where this meeting with the filmmaker took place.

Kinema: How did you get into filmmaking?

Jeffery Jeturian: I studied broadcasting communication at the University of Philippines. That was supposed to be for television but right after school I went into film production. I started out as a production assistant and worked my way up into being a director. I worked as a script supervisor and as production designer. When I was given a break to do my first film it was a low budget film which cost around 40,000 US\$. I was given only 10 days to finish everything and 20,000 feet of film negative. I was confident I would be able to do it because I had training in television. In the Philippines, TV movies are made in 2 days, so being given a 10-day shoot to do a film was considered quite a picnic.

\section{What kind of subjects interest you?}

I've done 3 films so far. I started directing in1998, so that's about one film a year. Fetch a Pail of Water is my second film, and my third film Larger than Life (Tuhog) was released in Manila in February 2001 where it got the best picture award in a critics' group. I'm excited about that one because it is very different from the past two films that I made, including Fetch A Pail of Water. The original title, Pila-balde, means lining up for water but it has a sexual connotation to it. It means gang bang, a girl with guys lining up to have sex with her. What interests me are personal stories, intimate stories. But in the process, I would also like to capture the political and social background of my characters.

Fetch A Pail of Water is a film focusing on social issues but which has a rather surprising amount of sex in it. What made you decide on this combination?

It's because of the industry conditions. Before you can do any substantial story, the producer requires you to put in a lot of sex, and that's what they asked me when I presented the material. The first thing that my supervising producer asked me was if I could put in a lot of sex. I thought about it and I thought it wouldn't harm the film if I put in a little sex except that after watching it at the festival last Sunday, I felt I somehow went overboard. But you know, that's why I'm all excited about my third film because it's is a parody of the sex films that we do back home. It's my revenge on my producer!

\section{How did the script for Fetch A Pail of Water come about?}

Actually that material had already been done for television. I worked as production designer in that drama episode about ten years ago. It was one of the materials I took note of and promised that if ever I became a director, I'd do something like that. So I asked the writer to update and revise it which he did.

My quarrel with local films is that they usually romanticise or dramatise poverty - which is not the way Filipinos look at poverty. I myself am amazed at the disposition of the Filipinos. They enjoy life and that's what I wanted to capture in my film. Not even poverty can stop them from loving, from keeping on their struggles, from living, and I hope that is clear in my film because in the end, the message is, even if there's so much tragedy in the lives of these people, life still goes on for them.

If you noticed, the main characters, even if they are young, know how to make ends meet. They know how to make a living just by fetching water, by driving a tricycle or even prostituting themselves. That goes for most Filipinos. A mother concerned about feeding her brood will go abroad and provide money for the family. But what is sad is when they come back, their children don't know them any more because they've been separated from them for several years. So the purpose of them going abroad and providing a living is somehow defeated because the family that they wanted to keep alive and intact somehow disintegrates 
with their being separated from them. The underlying reason is economical. Because there aren't enough opportunities for us back home to earn and make money.

In the film the class consciousness between the better-off Filipinos in the tenements and those who live in the slums seems very pronounced...

But you know, this is what is ironic because the lady who lives in the tenement housing isn't really that rich except that she's probably a notch higher than the poor folks but that somehow gives her license to oppress those under her and that is common with us. It saddens me that for most Filipinos who are poor, they look up to people with money regardless of how that person got his money. We've got a warped value system that puts premium on wealth rather than on integrity or honesty. It's a very materialistic world, probably brought about by our being economically poor. But you know, the way I made the film is reflective of our economy also. I did it for 50,000 US\$. I shot it in thirteen days and for the fire scene at the end, I was given by my producer just 500 US $\$$. To mount it, I had to be very creative and resourceful without sacrificing the story-telling. But that's good discipline because when the time comes that I am given a bigger budget, I can probably produce an epic for very little money!

Was the film shot in the slums?

Yes, but it was not in the heart of Manila. It was shot in Quezon City, adjacent to Manila but still within metro Manila. When you shoot in the slums, it's so difficult to control the crowd. That was one of my fears before I shot the film. The other fear was: how will I do the sex scenes? My first film was a very wholesome family drama but it bombed at the box office. But it got awards and it won for the actress a best actress award. So in my second film, I was ready to inject some sex into it just to be able to prove to my producer that I can be a mainstream director. And also because I thought the material could stand some sex. That was the only way I could convince my producer to allow me to do a socially relevant subject. Otherwise, I don't think she would allow me to do that kind of film for mainstream cinema.

While I was shooting, I kept postponing the time when I would have to do my first sex scene. I was apprehensive about how I was going to instruct my actors since I myself don't have any sexual experience with women. So for me, most of my exposure comes from the movies. But I finally got round to filming it on the eighth or ninth day - the scene where Gina, the main character is selling some snacks and she goes into this house where a girl is doing it with a guy, and she sees them both. That was the first sex scene I had to do and I did it for about eight hours, the whole acrobatic act. But after that, you know, I enjoyed doing it! So for the rest of the shooting, I had fun doing the other sex scenes. But for me what was very important were the two sex scenes of Gina because they were not just sexy scenes, they contained the heart of Gina's story. The first love scene was when she was used by this guy whom she thought loved her. The next love scene was more an act of desperation for Gina and the other guy who really loves her, so I didn't think it was erotic at all. I thought it was very sad when she pleaded with him not to make her a whore, embracing him tightly, fearing that he would do the same as the guy in the first sex act, who just flipped over and ignored her after he had finished.

The characters themselves seem very open about sex. Does this reflect the general attitude of Filipinos towards sex or is it a kind of liberation from the pressures of daily life?

If it's a kind of liberation, its not something conscious on their part. Generally, Filipinos are sexually liberated. They do it on the sly but somehow they're casual about their sexual needs and sexual relations. As one film programmer who has been to Manila said to me a few days ago, he thinks Manila is one big pickup place because everybody tries to make eye contact with everyone else. So I think the sexual promiscuity shown in the film is reflective of the way we regard sex even though the country is mostly Catholic.

There's a lot of hypocrisy in my country. Like right now we have a very conservative censor's chief who tells us how to execute our love scenes. From now on we have to do it in such a way that before the love scene starts, we close the door and just show the clothes being strewn on the floor. My film was made at the time when the censor's chief was quite liberal. So the freedom to do such scenes depends on the orientation of whoever is in charge of censorship at the time. The choice of this head of the Board of Censors was recommended by the Church, so that explains the government's conservatism.

Who is your target audience for Fetch A Pail of Water?

It's for the audience who loves to watch sex films, that's why it has a naughty title. But at the same, I was 


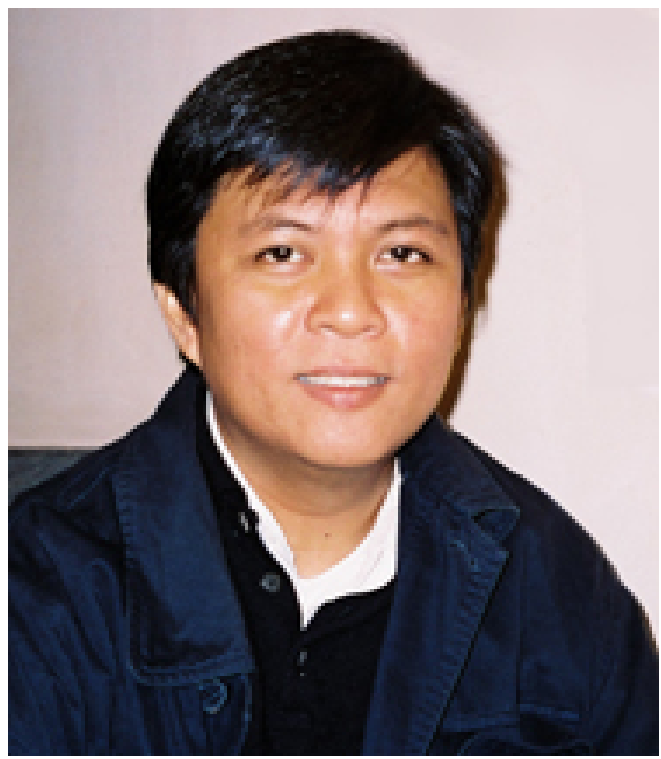

Figure 1: Director Jeffery Jeturian

hoping that even if they are there for the sex, they'd realise it's not just an ordinary sex film. If I consistently do films of this sort, then probably I would create an audience for my movies, more than just having viewers who are after sex. My target is also people who go for good cinema. Because my first film got good reviews and my second film got good reviews, I'd like to think I'm succeeding in creating an audience for my films.

\section{Do you think a film such as Fetch A Pail of Water can have any real social impact in the Philippines?}

No, not in my country. It doesn't take just one film to create that impact. It has to be a wave of filmmakers who make socially relevant films. But, you know, it is enough for me if I touch one person and make him think about the realities that he lives in. Then I think I have succeeded as a filmmaker in conveying the message in my film. I'm glad the film got good reviews because people watch it.

\section{Do the people who live in the slums go to see the film?}

No, because the cost of tickets is prohibitive. ${ }^{(1)}$

Most people cannot afford to go to the cinema any more. That's why our movie industry is on a downswing. So the people who are reflected in the film won't even get to see it. But if the people who can afford to buy the tickets are affected by what they see, then there's a chance they'll do something about it.

\section{How would you compare Larger than Life to Fetch A Pail of Water?}

Fetch A Pail of Water is Neorealist in style, there's not much cinematic manipulation and I tried to keep it as simple as possible. My third film Larger than Life is of a higher concept in the sense that it operates on several levels. The story is about a mother and daughter who were both incest victims. A film director and a film producer take an interest in their story which they read in a tabloid and they set out to buy the story rights from the mother and daughter to make a film. When the mother and daughter see the finished product, they feel raped all over again because of all the sex elements and distortions that have been added to make it into a commercial movie.

It's also a parody of Philippine's cinema, the way we do films, the way we hype everything just to make it "cinematic". It's also a dig at our tendency to make our films look like Hollywood. It was written by the same writer who did Fetch A Pail of Water. In the very first sequence, there's this film director who's proposing the film material and the producer approves it but gives instructions to the director to make the film very sexy - the same thing that happened to me. And that gives him license to distort the story.

Are you pleased with how your film career is developing? What are you working on now? 
I'm quite satisfied with the way my career is going and with the response to my first three films. I think I have to maintain the kind of films that I am starting to be known for - personal intimate stories that say a lot about our social and political realities. At the same time, I want to keep the casualness in my films, even if I tackle heavy material. I want to keep it at a level where the message is accessible to the general audience and I don't want it to be very cerebral.

My next film will be another parody. It's about a ticket seller at a movie house, who, to break the routine of her job, is prone to fantasizing about the people she sees in front of her booth. Unknown to her boyfriend, she's pregnant and it's this apprehension that sets her fantasizing. It's actually a dig at our penchant for romance, and again, a dig at Hollywood fantasies.

\section{Where do you get inspiration for your films?}

From newspaper accounts. For instance, for the film I'll be doing next, I read an article about what goes on in the day of a life of a ticket seller and from there I created a story and asked my writer to write the screenplay. Sometimes I confer with my writer and he suggests stories to me. It's a good thing that we agree - we think on the same level and what is interesting to him appeals also to me. My first three films had the same writer but for the Ticket Seller (Takilyera), I'm trying out another one so I wouldn't be that dependent on my favourite writer, so that when he goes, it would not mean the end of my career as well! But anyway, the new one I've got is his student, more or less, and they think along the same lines.

\section{Any final comment?}

Well, this festival was an eye opener for me. Even though Fetch A Pail of Water has already played at several international film festivals, it was the first time I had watched it along with an international audience and I was heartened by the reaction. Somehow, I knew that it had connected with them. People who saw the film approached me and told me they were touched by it. It is an affirmation that I have to keep doing the same kind of film - for people to see how lucky they are and how unlucky some people can be also! And to erase the barriers of discrimination and prejudice.

As I said in my speech before the start of the film, on my way to Italy, I was surprised to see that on the plane, there were a lot of Filipinos who were also heading for Italy. Sitting right beside me was a middle-aged Filipina who spent her vacation in the Philippines and was on her way back to Italy. She's a domestic helper here and has been staying in Italy for about twelve years. It pained me to think that while I was on an all expenses paid trip to Italy, many of my country men and women are leaving their families and homes behind to eke out a living. I hope my film will give the audience an idea of the conditions back home that drive the Filipinos away from their country in search of greener pastures, and that somehow, after watching my film, they will regard migrant workers in a more compassionate and enlightened way.

(Udine, Italy, April 2001)

\section{Notes}

1. A movie ticket in the Philippines now costs about US\$2. As of July 2001, the average daily minimum wage rate is about US\$ 4.16 .

\section{Author Information}

Yvonne NG is the co-author of Latent Images: Film in Singapore Second edition (NUS Press, 2010); Latent Images: Film in Singapore (OUP, 2000) and Latent Images: Film in Singapore CD-ROM (Singapore, 2003). She has written on Singapore and Asian cinema and contributes to the International Film Guide. 


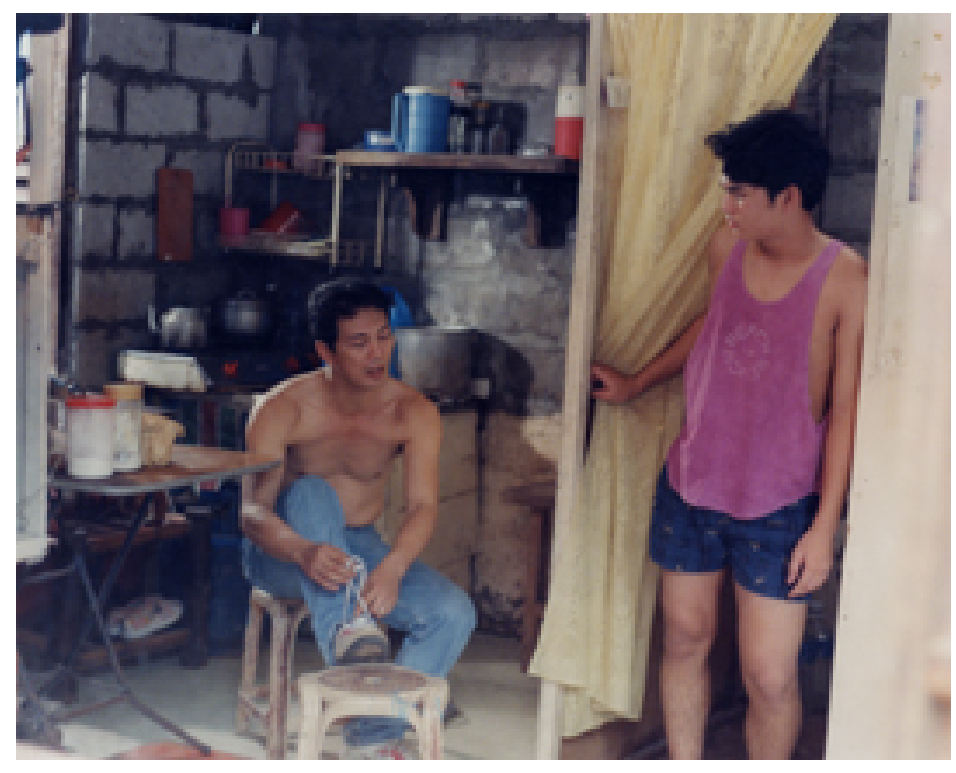

Figure 2: Fetch a Pail of Water 